\title{
Microbial diversity of Loki's Castle black smokers at the Arctic Mid-Ocean Ridge
}

\author{
A. JAESCHKE, ${ }^{1}{ }^{*}$ S. L. JØRGENSEN,${ }^{2}$ S. M. BERNASCONI, ${ }^{1}$ R. B. PEDERSEN ${ }^{3}$ \\ I. H. THORSETH ${ }^{3}$ AND G. L. FRÜH-GREEN ${ }^{1}$ \\ ${ }^{1}$ Department of Earth Sciences, ETH Zurich, Zurich, Switzerland \\ ${ }^{2}$ Department of Biology, Centre for Geobiology, University of Bergen, Bergen, Norway \\ ${ }^{3}$ Department of Earth Sciences, Centre for Geobiology, University of Bergen, Bergen, Norway
}

\begin{abstract}
Hydrothermal vent systems harbor rich microbial communities ranging from aerobic mesophiles to anaerobic hyperthermophiles. Among these, members of the archaeal domain are prevalent in microbial communities in the most extreme environments, partly because of their temperature-resistant and robust membrane lipids. In this study, we use geochemical and molecular microbiological methods to investigate the microbial diversity in black smoker chimneys from the newly discovered Loki's Castle hydrothermal vent field on the Arctic Mid-Ocean Ridge (AMOR) with vent fluid temperatures of $310-320^{\circ} \mathrm{C}$ and $\mathrm{pH}$ of 5.5 . Archaeal glycerol dialkyl glycerol tetraether lipids (GDGTs) and H-shaped GDGTs with 0-4 cyclopentane moieties were dominant in all sulfide samples and are most likely derived from both (hyper)thermophilic Euryarchaeota and Crenarchaeota. Crenarchaeol has been detected in low abundances in samples derived from the chimney exterior indicating the presence of Thaumarchaeota at lower ambient temperatures. Aquificales and members of the Epsilonproteobacteria were the dominant bacterial groups detected. Our observations based on the analysis of $16 \mathrm{~S}$ rRNA genes and biomarker lipid analysis provide insight into microbial communities thriving within the porous sulfide structures of active and inactive deep-sea hydrothermal vents. Microbial cycling of sulfur, hydrogen, and methane by archaea in the chimney interior and bacteria in the chimney exterior may be the prevailing biogeochemical processes in this system.
\end{abstract}

Received 13 April 2012; accepted 16 August 2012

Corresponding author. Andrea Jaeschke. Tel.: +41 44 6326349; fax: +41 44 6321636; e-mail: andrea. jaeschke@erdw.ethz.ch

\section{INTRODUCTION}

Deep-sea hydrothermal vents are unique environments that support highly productive ecosystems driven by geochemical energy and have been proposed as a possible site for the origin and early evolution of life (Baross \& Hoffman, 1985; Martin et al., 2008). The distinctive black smoker chimneys at submarine hydrothermal environments are formed when sulfates and sulfides precipitate due to mixing of hot, acidic, and anoxic vent fluids with cold oxic seawater, thus creating steep thermal and chemical gradients along and inside the chimney (Tivey, 1995). Migrating fluids contain reduced inorganic and organic components providing metabolic energy for diverse thermophilic microbial communities that inhabit either specific microniches in different parts of the porous chimney structure, appear as free-living micro-organisms in vent fluids and plumes, or occur as symbionts of vent macrofauna (Karl, 1995). These micro-organisms are adapted to a habitat characterized by extreme environmental conditions such as high temperature and pressure, low $\mathrm{pH}$ as well as elevated concentrations of dissolved gases $\left(\mathrm{H}_{2} \mathrm{~S}, \mathrm{H}_{2}, \mathrm{CO}_{2}, \mathrm{CH}_{4}\right)$ and metal sulfides (Miroshnichenko, 2004).

Since the discovery of deep-sea hydrothermal vent systems in the late 1970s (Corliss et al., 1979), enrichment and isolation studies as well as culture-independent approaches, which mainly involved molecular studies of the 16S rRNA gene, were performed. These studies revealed a remarkable microbial diversity with numerous so far uncultivated organisms thriving in these extreme and unstable habitats (Takai et al., 2001; Schrenk et al., 2003; Alain et al., 2004; Kormas et al., 2006; Sogin et al., 2006). 
Hyperthermophilic archaea tend to be dominant in the high temperature zones of the chimney interiors, whereas both archaea and bacteria are present in the cooler exterior parts where mixing with seawater is more prevalent (Schrenk et al., 2003). Along with the apparent temperature zonation, where distinctive micro-organisms can thrive, different metabolisms are thermodynamically available. For example, oxidation of methane, ammonia, and sulfur are favored at low temperatures toward the chimney exterior, while methanogenesis and reduction of sulfate or sulfur is favored at higher temperatures toward the chimney interior (McCollom \& Shock, 1997; Takai et al., 2001; Schrenk et al., 2003; Kormas et al., 2006; Takai \& Nakamura, 2011).

In addition to molecular techniques, organic geochemical approaches can be employed to reveal microbial community structures by analyzing lipid biomarkers. Archaea synthesize distinctive membrane lipids predominantly composed of diether lipids (i.e., archaeol, hydroxyarchaeol) and isoprenoid glycerol dialkyl glycerol tetraethers (GDGTs). GDGTs with an additional covalent bond, so-called $\mathrm{H}$-shaped GDGTs, have so far only been reported for cultivated isolates of (hyper-) thermophilic archaea (Morii et al., 1998; Sugai et al., 2004; Koga \& Morii, 2005; Schouten et al., 2008). GDGTs are excellent biomarkers to use in hydrothermal vents as they are community-specific and resistant to extreme environmental conditions (Derosa \& Gambacorta, 1988; van de Vossenberg et al., 1998; Macalady et al., 2004). There are, however, only few studies carried out on biomarker lipids in deep-sea hydrothermal vents indicating possible microbial communities with their potential metabolisms (Blumenberg et al., 2007; Blumenberg et al., 2012; Bradley et al., 2009).

Loki's Castle is a deep-sea hydrothermal vent field located at the ultra-slow spreading Arctic Mid-Ocean Ridge (AMOR) in the Norwegian-Greenland Sea at $74^{\circ} \mathrm{N}$. Discovered in 2008, it is the northernmost black smoker field known to date and hosts a unique ecosystem (Pedersen et al., 2010). It is a sediment-associated system, and therefore, hydrothermal fluids contain an unusual enrichment of carbon dioxide, methane, and ammonia, providing potential for various energy metabolisms and diverse microbial populations. Here, we report first insights into the microbial assemblages inhabiting active and inactive sulfide chimneys of the Loki's Castle hydrothermal vent field based on biomarker lipid analysis and 165 rRNA gene-based taxonomy.

\section{STUDY AREA AND SAMPLING}

The Knipovich Ridge is one of the AMOR spreading centers in the Norwegian-Greenland Sea, and the southernmost part of this ridge is one of the slowest spreading ridge segments on Earth. The Loki's Castle vent field is located at $2400 \mathrm{~m}$ water depth on an axial volcanic ridge (AVR) where the magma-starved end of the Mohns Ridge migrates into the Knipovich Ridge through a sharp northward bend in the direction of the spreading axis at $73^{\circ} 30^{\prime} \mathrm{N}$ and $8^{\circ} \mathrm{E}$ (Fig. 1) (Pedersen et al., 2010). At the seafloor, black smoker fluids are discharging from four, up to $13 \mathrm{~m}$ tall, chimneys. The chimneys are situated on two hydrothermal mounds that are approximately $150 \mathrm{~m}$ apart and are estimated to be $20-30 \mathrm{~m}$ high and about 150 $200 \mathrm{~m}$ across. The mounds of Loki's Castle are comparable in size with the TAG-mound (Trans-Atlantic Geotraverse) on the Mid-Atlantic Ridge (Pedersen et al., 2010). The four active chimneys were named João, Menorah, Camel, and Sleepy. João is the tallest of the four chimneys, situated on the eastern sulfide mound.

The hydrothermal fluids from Loki's Castle reach temperatures of $310-320^{\circ} \mathrm{C}$ and have a pH of 5.5. The vent fluid compositions are characterized by high concentrations of $\mathrm{CH}_{4}, \mathrm{H}_{2}$, and $\mathrm{NH}_{4}$, as well as elevated concentrations of higher hydrocarbons, and are indicative of a sediment-impacted hydrothermal vent system (Pedersen et al., 2010; Baumberger, 2011). Significant sediment accumulation is not present at the volcanic ridge hosting the field. However, the rift valley of the southern Knipovich Ridge in the vicinity of Loki's Castle is partly buried by a thick sediment cover. These sediments, derived from the nearby Bear Island fan, likely underlie the AVR and influence hydrothermal fluid compositions (Pedersen et al., 2010; Baumberger, 2011).
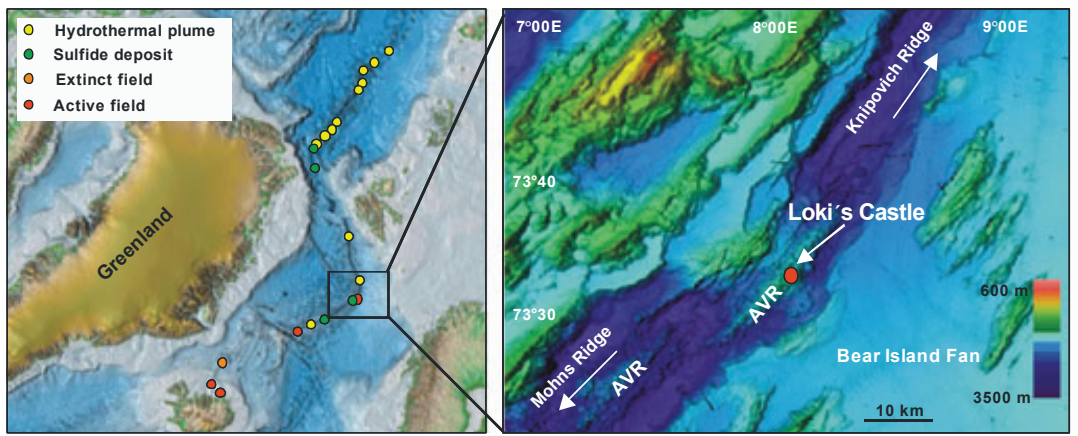

Fig. 1 Location of the Loki's Castle vent field at the Arctic Mid-Ocean Ridge (AMOR). AVR, Axial Volcanic Ridge. 
Table 1 Bulk data of chimney samples and microbial filaments from Loki's Castle black smokers

\begin{tabular}{|c|c|c|c|c|c|c|c|}
\hline Dive & Chimney & Sample material & Sample part & TOC (\%) & $\delta^{13} \mathrm{C}(\%)$ & $\delta^{34} S(\%)$ & Major mineral composition, color, texture \\
\hline GS08-ROV10(1) & João & Active & Interior & 0.09 & -19.0 & 4.3 & Amorphous silica rich; gray, relatively hard material \\
\hline GS08-ROV10(2) & João & Active & Interior & 0.10 & -24.9 & N.a. & Anhydrite; gray, soft material \\
\hline GS09-ROV9 & João & Filaments & Exterior & 12.11 & -27.1 & n.a. & Thin, white filaments \\
\hline GS10-ROV9(1) & João & Active & Middle & 0.86 & -36.0 & 1.0 & Marcasite, sphalerite; black soft material \\
\hline GS10-ROV9(2) & João & Active & Middle & 0.17 & -39.3 & 1.7 & Marcasite, sphalerite, pyrite; black soft material \\
\hline GS08-ROV11(1) & Menorah & Active & Interior & 3.12 & -14.2 & 2.1 & Sphalerite, pyrrhotite, pyrite; black soft material \\
\hline GS08-ROV11(2) & Menorah & Active & Interior & 0.11 & -24.3 & 2.3 & Pyrite; black soft material \\
\hline GS08-ROV11(3) & Menorah & Active & Interior & 0.09 & -22.7 & 2.5 & Sphalerite, pyrrhotite; black soft material \\
\hline GS08-ROV11(4) & Menorah & Active & Interior & 0.03 & -15.3 & n.a. & Sphalerite, pyrrhotite; black soft material \\
\hline GS09-ROV6(1) & No name & Inactive & Exterior & 0.06 & -6.8 & 18.5 & Anhydrite, gypsum, talc; gray, relatively soft material \\
\hline GS09-ROV6(2) & No name & Inactive & Exterior & 0.11 & -6.0 & 21.0 & Anhydrite, gypsum; gray, relatively soft material \\
\hline
\end{tabular}

n.a. not analyzed. Numbers in brackets indicate subsamples taken from same chimney wall.

Table 2 Taxonomic affiliation, abundances and $16 \mathrm{~S}$ rRNA gene numbers of microbial populations of Menorah bulk chimney material (GS08-ROV11)

\begin{tabular}{llr}
\hline $\begin{array}{l}\text { Taxonomic level } \\
\text { Phylum }\end{array}$ & Taxonomic level Class & $\begin{array}{c}\text { \% of prokaryotic SSU } \\
454 \text { sequence reads }\end{array}$ \\
\hline Proteobacteria & Gammaproteobacteria & 0.2 \\
Proteobacteria & Betaproteobacteria & 0.1 \\
Proteobacteria & Epsilonproteobacteria & 36.1 \\
Proteobacteria & Deltaproteobacteria & 0.1 \\
Firmicutes & Clostridia & 0.1 \\
Deferribacteres & Deferribacterales & 0.1 \\
Thermotogae & Thermotogae & 0.6 \\
Aquificae & Aquificae & 26.1 \\
Thermodesulfobacteria & Thermodesulfobacteria & 0.8 \\
Candidate division SR1 & - & 0.8 \\
Chloroflexi & Dehalococcoides & 0.1 \\
Crenarchaeota & Thermoprotei & 0.9 \\
Euryarchaeota & Thermoplasmata & 0.3 \\
Euryarchaeota & Methanococci & $\mathbf{2 . 8}$ \\
Euryarchaeota & Archaeoglobi & $\mathbf{1 . 8}$ \\
Euryarchaeota & Thermococci & $\mathbf{2 8 . 4}$ \\
Thaumarchaeota & Marine Group I & 0.1 \\
\hline
\end{tabular}

Bold font indicates taxonomic groups represented by more than $1 \%$ of the total $16 \mathrm{~S}$ rRNA gene pool.

The chimney samples analyzed in this study were collected during R/V G.O. Sars cruises in 2008, 2009, and 2010 using a Bathysaurus XL remotely operated vehicle (ROV) equipped with a hydraulically operated box sampler. In total, eleven samples recovered from two active and inactive sulfide structures (Menorah, João, and one unnamed chimney) at Loki's Castle hydrothermal vent field were subsampled and analyzed for mineral composition and lipid biomarkers (Table 1). From Menorah, a bulk sample from the chimney wall was sampled for 16S rRNA gene analysis (sample GS08-ROV11; Table 2). In addition, microbial filaments at the surface of the João structure were sampled by a suction sampler and analyzed for lipid biomarkers. All samples were stored at $-20^{\circ} \mathrm{C}$ until used for analysis.

\section{MATERIALS AND METHODS}

\section{Rock analyses}

Freeze-dried, crushed, and powdered chimney samples were analyzed by X-ray diffraction (Bruker, AXS D8 Advance) to determine the mineralogy. Total organic carbon (TOC), carbon isotope ratios $\left(\delta^{13} \mathrm{C}\right)$, and sulfur isotope ratios $\left(\delta^{34} S\right)$ of the bulk rock samples were measured after decarbonation on a ThermoFisher Flash-EA 1112 elemental analyzer coupled via a Conflo IV interface to a ThermoFisher Delta V isotope ratio mass spectrometer. The system was calibrated with the reference materials NBS22 $\left(\delta^{13} \mathrm{C}=-30.03\right)$ and IAEA CH- $6\left(\delta^{13} \mathrm{C}=-10.46\right)$ for carbon and IAEA $-S-1 \quad\left(\delta^{34} S=-0.3\right)$, IAEA $-S-2$ $\left(\delta^{34} S=+22.67\right)$, IAEA $-S-3\left(\delta^{34} S=-32.55\right)$ for sulfides and NBS $127\left(\delta^{34} S=+21.1\right)$, IAEA-SO-5 $\left(\delta^{34} S=+0.49\right)$ and IAEA-SO- $6\left(\delta^{34} S=-34.05\right)$ for sulfates. All analytical results are reported in the conventional $\delta$ notation, in per mil relative to the Vienna Pee Dee belemnite (VPDB) standard for carbon and the Vienna Canon Diablo Troilite (VCDT) standard for sulfur. Reproducibility of the measurements was better than $0.2 \%$.

\section{Molecular techniques and taxonomic analysis}

DNA extraction and PCR amplification

Ten-gram of bulk chimney wall material from the active Menorah structure (GS08-ROV11) was pulverized in a sterilized steel mortar, and DNA was extracted from this homogenized material (approximately $0.5 \mathrm{~g}$ ) using a FastDNA $^{(\mathbb{R}}$ spin kit for soil in conjunction with the FastPrep instrument (MP Biomedicals, Santa Ana, CA) following manufactures protocol and applying the modifications described by Hugenholtz et al. (1998). The extracted DNA was PCR amplified in triplicates using the prokaryotic primer set 787F (5'ATTAGATACCCNGG TAG3') (Roesch et al., 2007) and Unil391R (5'ACGGG CGGTGWGTRC3') modified from Lane et al. (1985), as 
described by Lanzén et al. (2011). The resulting amplicons were purified and sequenced using multiplex GS FLX pyrosequencing (without Titanium chemistry) at the Norwegian High-Throughput Sequencing Centre (NSC) in Oslo, Norway.

Filtering, removal of noise and taxonomic assignment of 16S rRNA gene amplicon sequence data

The dataset (5485 reads) was filtered and cleaned from noise by using the software AmpliconNoise (Quince et al., 2011). The protocol has been described previously (Lanzén et al., 2011). In short, bad-quality reads are removed (flow intensity $0.5-0.7$ ), so are sequences not matching the applied primer sequence as well as chimeric reads. The resulting 3646 high-quality reads distributed on 122 unique reads with an average read length of 231 bp were used for taxonomic evaluation. To assign each sequence read to a taxon, we compared our reads with the SILVA SSUref database release 100 (Pruesse et al., 2007), using blastn. A manual revision of this database was conducted, and the taxonomy updated with respect to Epsilonproteobacteria, Acidobacteria, Chloroflexi, and the Archaea as well as a more restrictive quality filter (pintail score $>75$, alignment quality $>75$ and length $>1200 \mathrm{bp}$; database available at http://services.cbu.uib.no/supplementary/ community-profiling/). Taxomomical assignments were then evaluated using the software MEGAN version 3.7 (Huson et al., 2007) by applying a last common ancestor algorithm (for details see Lanzén et al., 2011). Taxonomic affiliation of sequence reads and the relative abundances within the bulk chimney wall of the Menorah structure are given in Table 2. Pyrosequencing flowgrams (SSF files) have been deposited in the NCBI Sequence Read Archive under the accession number SRA052614.

\section{Lipid extraction, derivatization, and fractionation}

About 6-12 g of each chimney sample was freeze-dried, crushed to a fine powder, and ultrasonically extracted using methanol $(\mathrm{MeOH})$, dichloromethane (DCM)/MeOH $(1: 1 \mathrm{v} / \mathrm{v})$, and DCM (three times). The extracts were combined and the bulk of the solvent subsequently removed by rotary evaporation under vacuum. Elemental sulfur was removed from the total lipid extract (TLE) by flushing with n-hexane over a small pipette filled with $\mathrm{HCl}$-activated copper. The TLE was further transmethylated with $\mathrm{MeOH} /$ $\mathrm{HCl}(10 \% \mathrm{w} / \mathrm{v})$ at $70{ }^{\circ} \mathrm{C}$ for $2 \mathrm{~h}$ to convert free and esterbound fatty acids into their corresponding methyl esters (FAMEs), and silylated with bis (trimethyl) trifluoroacetamide (BSTFA) in pyridine at $60{ }^{\circ} \mathrm{C}$ for 20 min to convert alcohols in trimethylsilyl (TMS) ether derivatives. An aliquot of the TLE was chromatographically separated into apolar and polar fractions using a column with activated silica as stationary phase. Apolar compounds were obtained using n-hexane/DCM $(9: 1 \mathrm{v} / \mathrm{v})$ as eluant. Polar fractions containing the GDGTs (i.e., structures I-XII, Fig. 3) were eluted with $\mathrm{DCM} / \mathrm{MeOH}(\mathrm{l}: 1 \mathrm{v} / \mathrm{v}, 3$ column volumes). After solvent evaporation, the polar fractions were redissolved in $200 \mu \mathrm{L}$ of HPLC-grade $\mathrm{n}$-hexane/isopropanol $(99: 1 \mathrm{v} / \mathrm{v})$ and were filtered through a $0.45-\mu \mathrm{m}$ PTFE filter prior to HPLC/APCI/MS analysis. Microbial filaments were extracted using a modified Bligh-Dyer procedure (Bligh \& Dyer, 1959). A solvent mixture of phosphate-buffer $(0.05 \mathrm{M}, \mathrm{pH} 7.4) /$ methanol $(\mathrm{MeOH}) /$ dichloromethane (DCM) $0.8 / 2 / 1(\mathrm{v} / \mathrm{v})$ was added to the frozen cell material. The mixture was sonicated for $10 \mathrm{~min}$ after which further DCM and phosphate-buffer were added to a volume ratio of $0.9 / 1 / 1$. After centrifuging $(5 \mathrm{~min}$ at $1120 \mathrm{~g}$ ), the DCM layer was collected. The residue was re-extracted twice following the same procedure. The extracts were combined and the bulk of the solvent subsequently removed by rotary evaporation under vacuum. An aliquot of the extract was further hydrolyzed in $2 \mathrm{M} \mathrm{HCl} /$ $\mathrm{MeOH}(1 / 1, \mathrm{v} / \mathrm{v})$ for $3 \mathrm{~h}$ at $75^{\circ} \mathrm{C}$. The $\mathrm{pH}$ of the hydrolyzed extract was adjusted to $\mathrm{pH} 3$ using $1 \mathrm{~m} \mathrm{KOH}$ ( $\mathrm{MeOH} 96 \%)$. The extract was derivatized as described previously. The position of the double bonds in the fatty acids was determined by analysis as their dimethyl disulfide (DMDS) adducts according to the method of Nichols et al. (1986). Briefly, an aliquot of the sample dissolved in $50 \mu \mathrm{L}$ of n-hexane was treated with $100 \mu \mathrm{L}$ of DMDS and $20 \mu \mathrm{L}$ of iodine solution $(6 \% \mathrm{w} / \mathrm{v}$ in diethyl ether). The reaction was carried out in $2-\mathrm{mL}$ screw-cap glass vials at $50{ }^{\circ} \mathrm{C}$ for $48 \mathrm{~h}$. The mixture was cooled and diluted with $500 \mu \mathrm{L}$ of $\mathrm{n}$-hexane. The excess of iodine was reduced by addition of $500 \mu \mathrm{L}$ of sodium thiosulfate $(5 \% \mathrm{w} / \mathrm{v}$ in MilliQ water). The organic phase was removed, and the aqueous phase extracted twice with $500 \mu \mathrm{L}$ of $\mathrm{n}$-hexane. Combined organic phases were evaporated under a stream of nitrogen and diluted with $100 \mu \mathrm{L}$ of $\mathrm{n}$-hexane prior to GC-MS analysis.

\section{Analysis and identification of biomarkers}

\section{High-performance liquid chromatography-mass spectrometry (HPLC-MS)}

Glycerol dialkyl glycerol tetraethers analysis was performed at the Geological Institute of the ETH Zurich using highperformance liquid chromatography/atmospheric pressure chemical ionization-mass spectrometry (HPLC/APCI-MS) with a Thermo Surveyor LC system coupled to an LCQ Fleet ion trap mass spectrometer equipped with a PAL LC autosampler and Xcalibur software, as described by Hopmans et al. (2000). Normal phase separation was achieved with an Alltech Prevail Cyano column $(150 \mathrm{~mm} \times 2.1 \mathrm{~mm} ; 3 \mu \mathrm{m})$ maintained at $30^{\circ} \mathrm{C}$. Flow rate of the n-hexane/isopropanol (IPA) (99:1) mobile phase was $0.3 \mathrm{~mL} \mathrm{~min}^{-1}$, isocratically for the first $5 \mathrm{~min}$, thereafter 
with a linear gradient to $2 \%$ IPA in $30 \mathrm{~min}$, and a column cleaning step with $10 \%$ IPA in $n$-hexane. Injection volume was $20-50 \mu \mathrm{L}$. Scanning was performed over the $\mathrm{m} / \mathrm{z}$ ranges 740-746, 1016-1054, and 1280-1318. Relative abundances of GDGTs were calculated using peak areas of the $[\mathrm{M}+\mathrm{H}]^{+}$ions vs. those of the $\mathrm{C} 20$-diol internal standard $(m / z 743)$. GDGTs were identified and distinguished via their $\mathrm{MS}^{2}$ spectra. $\mathrm{MS}^{2}$ experiments were performed with conditions according to Knappy et al. (2009). Briefly, eluting species were monitored using the positive ionization mode of the APCI source. Conditions for APCI-MS were as follows: vaporizer temperature $300{ }^{\circ} \mathrm{C}$, sheath gas $\left(\mathrm{N}_{2}\right)$ flow rate 40 (arb. units), auxiliary gas $\left(\mathrm{N}_{2}\right)$ flow rate 5 (arb. units), capillary temperature $200^{\circ} \mathrm{C}$, capillary voltage $23 \mathrm{~V}$, and corona discharge current $5 \mu \mathrm{A}$. Positive ion MS spectra were obtained by scanning a narrow mass range from $\mathrm{m} / \mathrm{z}$ 1220 to $1350 . \mathrm{MS}^{2}$ spectra were recorded using the data dependent ion scan feature, in which the base peak of an MS scan is selected for collision induced dissociation (CID) in $\mathrm{MS}^{2}$ (collision energy was set at $30 \%$ ).

\section{Gas chromatography-mass spectrometry (GC-MS)}

Compound identification was done by combined GC-MS. GC-MS was conducted using a Hewlett Packard 6890 gas chromatograph equipped with an on-column injector. A fused silica capillary column (HP-5, $30 \mathrm{~m}$ length, $0.25 \mathrm{~mm}$ inner diameter, $0.25 \mu \mathrm{m}$ film thickness) with helium as a carrier gas was used. The gas chromatograph was interfaced to a HP 5973 mass selective detector (MSD) with a mass range of $m / z 50-800$. The samples were injected at $60^{\circ} \mathrm{C}$. The $\mathrm{GC}$ oven temperature was subsequently raised to $120^{\circ} \mathrm{C}$ at a rate of $10^{\circ} \mathrm{C} \mathrm{min}{ }^{-1}$ and then to $320^{\circ} \mathrm{C}$ at $4^{\circ} \mathrm{C} \mathrm{min}{ }^{-1}$. The temperature was then held constant for $20 \mathrm{~min}$. The structural characterization of lipids was evaluated by comparing their mass spectral fragmentation pattern with published spectra.

\section{RESULTS AND DISCUSSION}

\section{Mineralogy and bulk isotope data}

The mineralogy of the samples recovered from active (João and Menorah) and inactive sulfide chimneys (Table 1) indicated that they were mostly derived from the interior zones of the chimney wall. The sulfide-poor samples GS09ROV6 $(1+2)$ were dominated by abundant anhydrite, and less gypsum and talc. In general, during chimney growth, anhydrite precipitates around a black smoker vent at the leading edge of chimney growth, where hot hydrothermal fluids first encounter cold seawater (Haymon, 1983), talc forms in hot chimneys from seawater magnesium and hydrothermal silica (Haymon \& Kastner, 1981). Thus, we can assume that our samples containing anhydrite were derived from the exterior zones of the chimney wall. The porous sulfide samples mainly consisted of pyrite, pyrrhotite, sphalerite, and marcasite (Table 1), reflecting intermediate temperatures of formation $\left(<240{ }^{\circ} \mathrm{C}\right.$ for marcasite $)$ (Haymon, 1983). A number of studies have shown that once the anhydrite walls of a chimney are in place, and hydrothermal fluid is protected from extensive mixing with seawater, which subsequently leads to the precipitation of $\mathrm{Zn}-\mathrm{Cu}-\mathrm{Fe}$ sulfides toward the chimney interior. During this stage, anhydrite is partially dissolved again and replaced by sulfides (Haymon, 1983).

$\delta^{34} S$ values generally ranged from $1 \%$ to $2 \%$ in the sulfide samples (Table 1 ) indicating a mid-ocean ridge basalt (MORB) source (Shanks \& Seyfried, 1987). The sulfate samples (i.e., anhydrite) showed $\delta^{34} S$ values of $19 \%$ and $21 \%$, reflecting seawater sulfate values. Total organic carbon (TOC) was generally low in the chimney samples ranging from $0.03 \%$ to $0.9 \%$; however, GS08-ROVI1(1) of active Menorah revealed an extraordinarily high TOC content of $3 \%$ (Table 1 ). These strong variations in the organic content of samples from the same chimney indicate that hydrothermal vents provide small, patchy, and unstable habitats for microbes. The $\delta^{13} \mathrm{C}$ of organic carbon varied between -6 and $-7 \%$ for the inactive chimney samples which is in the range of the isotopic composition observed for mantle derived $\mathrm{CO}_{2} . \delta^{13} \mathrm{C}$ values of organic carbon in the active chimney samples varied from -14 to $-39 \%$, yielding a range of $25 \%$ (Table 1 ). The low $\delta^{13} \mathrm{C}$ values in the marcasite-bearing samples GS10-ROV9 $(1+2)$ of João may indicate the presence of chemolithoautotrophs preferentially using ${ }^{12} \mathrm{C}$ in a distinct layer within the middle/outer chimney wall where metastable pyrrhotite is being rapidly replaced by either pyrite or marcasite, depending on the $\mathrm{pH}$ of the fluid (for marcasite pH < 5) (Murowchick \& Barnes, 1986). Thus, besides variations in temperature and availability of reduced chemical species, the mineralogy and habitat type could be important factors affecting the composition of microbial communities (Kato et al., 2010).

\section{Microbial diversity}

The sulfide chimney matrix of the active Menorah structure (GS08-ROV11) harbored a diverse range of thermophilic and hyperthermophilic archaea and bacteria, as shown both by our 16S rRNA gene-based taxonomy (Table 2, Fig. 2) and lipid analysis (Fig. 3). However, lipids such as GDGTs are common lipids of many archaea, and therefore, it is difficult to link them with a specific archaeal group without additional microbial- or compound-specific isotope data. In the following sections, we use the information obtained from the 16S rRNA gene amplicon library to discuss the link between possible source organisms and different compound classes detected in samples originating from the same chimney wall. 


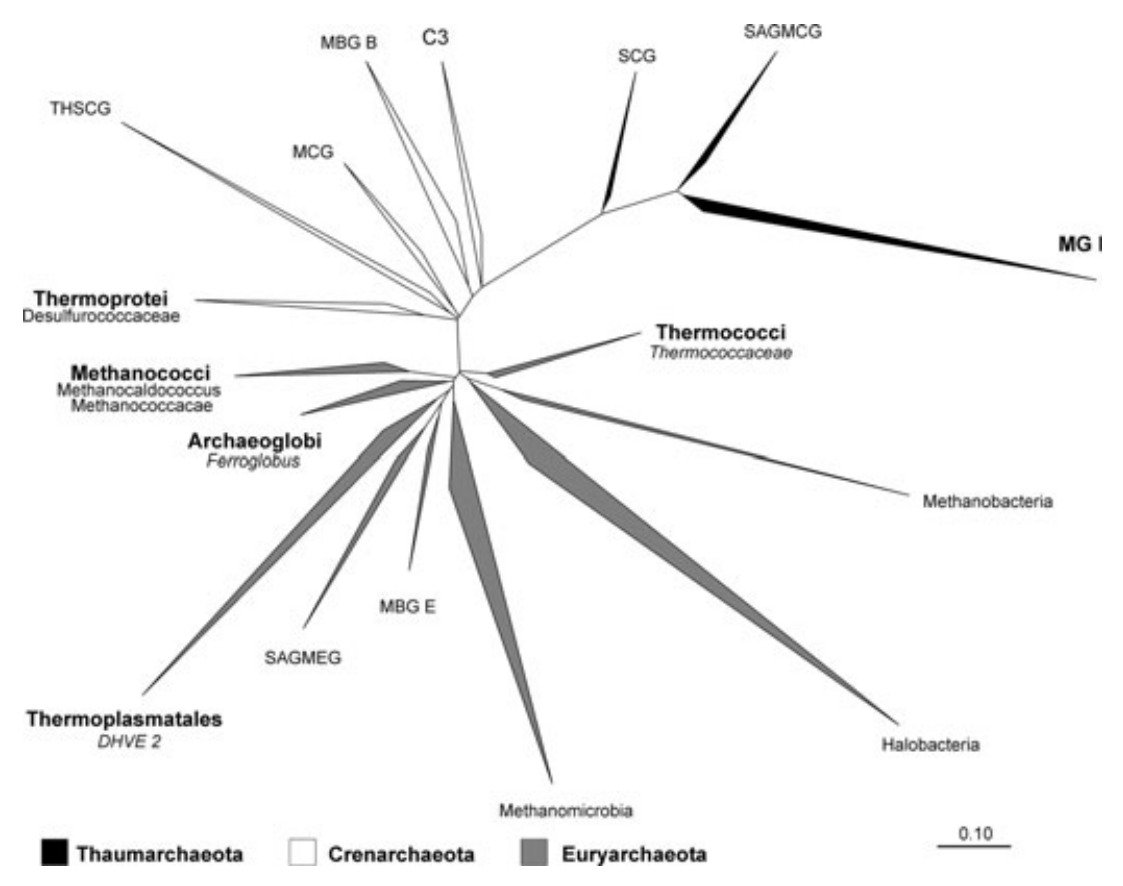

Fig. 2 Phylogenetic Neighbor-joining tree based on archaeal 16S rRNA gene sequence information. The taxonomic affiliation of the sequences obtained from the Menorah active sulfide chimney is highlighted in bold. Further the group to which these sequences could be assigned at a lower taxonomic level is given below the phylum name in italic. The relative abundance of each group can be found in Table 2. THSCG, Terrestrial hotspring crenar chaeotic group; MCG, Miscellaneous crenar chaeotic group; MBG, Marine Benthic Group; SCG, Soil crenarchaeotic group; SAGMCG, South African gold mine crenarchaeotic group; MG I, marine group I; SAGMEG, South African gold mine Euryarchaeotic group.

\section{Archaea}

Distribution and origin of archaeal GDGTs (I-VII)

All samples from the chimney structures contained a range of isoprenoid GDGTs (Fig. 3), indicating that archaea are present throughout the chimney walls. GDGT I, a trialkyltype GDGT (Fig. 3), was detected as a minor constituent $(<1 \%)$ of the total GDGT pool from Menorah and João active sulfide chimneys (Fig. 4). GDGT I has been reported in a number of cultivated thermophilic and hyperthermophilic Crenarchaeota (Gulik et al., 1988; de la Torre et al., 2008) and has been proposed as an intermediate in the biosynthesis of GDGT II from archaeol (Koga \& Morii, 2007). GDGT II (Fig. 3) was detected in all samples analyzed and was also the most abundant compound with relative abundances between 29 and $61 \%$ of all GDGTs, followed by GDGTs containing $1-4$ cyclopentane rings (Fig. 3 structures III-VI) with relative abundances between 1 and 19\% (Fig. 4). Methanogenic archaea and members of the family Archaeoglobaceae have been found to produce predominantly GDGT II (Koga \& Morii, 2005). Sequences related to both groups were found in our taxonomic data, namely members of the family Methanococcales and of the genus Ferroglobus belonging to the family of Archaeoglobales. Methanococcales (2.8\% of the total community) is a group that constitutes strictly anaerobic autotrophs that gain energy by the reduction of $\mathrm{CO}_{2}$ with $\mathrm{H}_{2}$, generating $\mathrm{CH}_{4}$. Ferroglobus made up $1.8 \%$ of the total community (Fig. 2) and is a hyperthermophilic (growth between 65 and $95^{\circ} \mathrm{C}$ ) member of the Archaeoglobales that oxidizes ferrous iron $\left(\mathrm{Fe}^{2+}\right)$ but also molecular hydrogen, and sulfide under strictly anaerobic conditions (Hafenbradl et al., 1996). Nitrate and thiosulfate $\left(\mathrm{S}_{2} \mathrm{O}_{3}{ }^{2-}\right)$ are used as electron acceptors that are known from a variety of hyperthermophiles (Stetter et al., 1987; Stetter, 2002). Although it seems likely that the origin of the detected GDGT II stems from the above-mentioned groups, we cannot exclude that there are other, still uncultivated archaeal groups that also produce this as a major lipid.

Detection of 16S rRNA genes related to hyperthermophilic members of the family Thermoproteaceae (Crenarchaeota) and Thermoplasmataceae (Euryarchaeota) (Table 2, Fig. 2) suggest that, at least partly, they may be the source organisms for GDGT III-VI containing 1-4 cyclopentane rings (Fig. 3). As reported by Koga \& Morii (2005), these groups have been found to predominantly synthesize GDGT II-VI in culture. Indeed, members of the Desulfurococcus, a group composed of hyperthermophilic heterotrophs, growing at temperatures up to $95^{\circ} \mathrm{C}$ (no growth is reported for temperatures of $\leq 65{ }^{\circ} \mathrm{C}$ ) and gaining energy by oxidation of hydrogen using elemental sulfur (Huber \& Stetter, 2006; Stetter, 2006), were detected as minor components representing $0.9 \%$ of the microbial community (Fig. 2). It is interesting to know that we found GDGTs with a maximum of only four rings in such high temperature environment. In general, the number of cyclopentane rings incorporated in tetraether lipids increases with increasing growth temperature (i.e., Uda et al., 2001; Schouten et al., 2002; Boyd et al., 2011). GDGTs with up to eight rings were reported from Yellowstone hot springs (Schouten et al., 2007), where 
Fig. 3 High-performance liquid chromato graphy (HPLC)/APCl/MS base peak chromato gram showing the distribution of GDGTs in Menorah active black smoker material GS08ROV11(1), and structures of GDGTs present in the black smokers of Loki's Castle. The position of the covalent bond between the isoprenoid hydrocarbon chains in GDGTs VIIXI is tentative (Morii et al., 1998). Cren, Crenarchaeol; GTGT, glycerol dialkyl glycerol tetraether; GDGT, glycerol dialkyl glycerol tetraether; H-GDGT, H-shaped GDGT (see text).

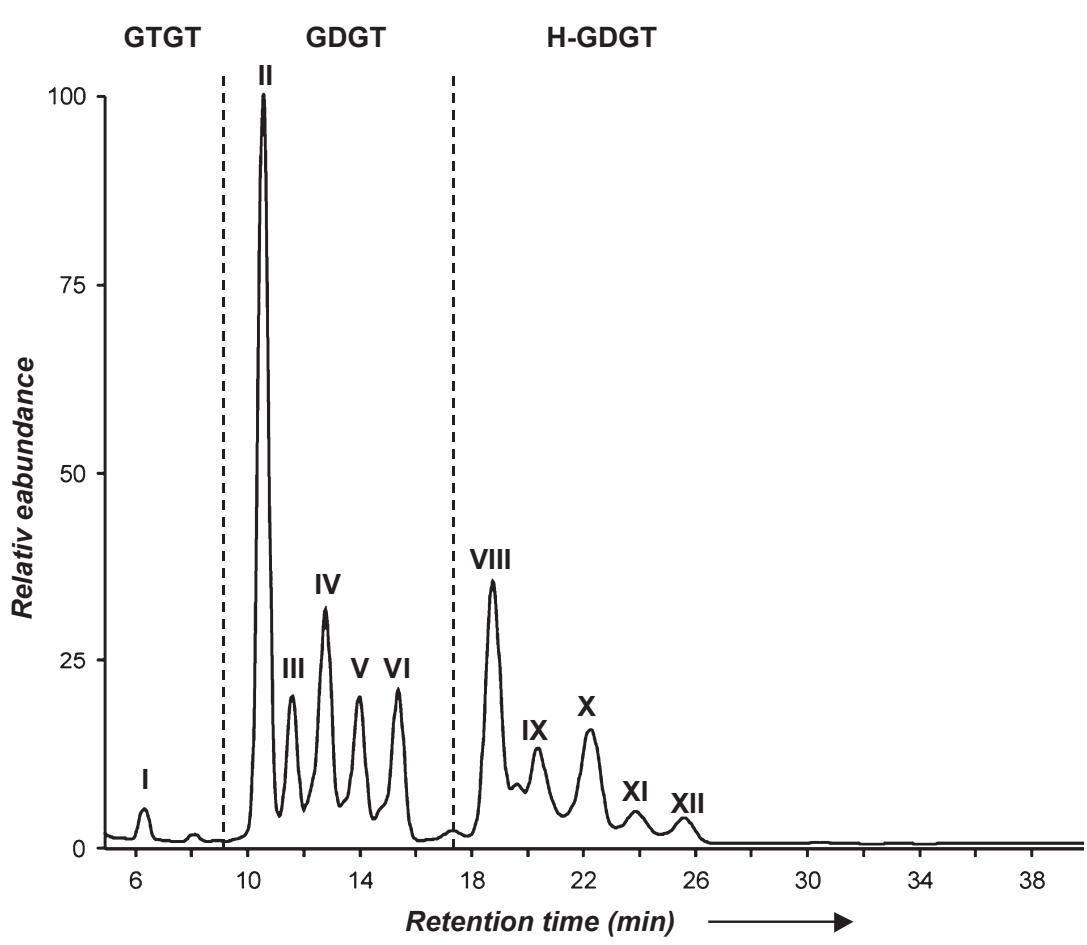

l.

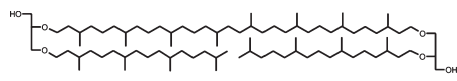

II.

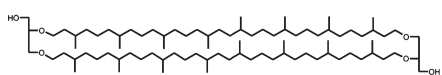

III.

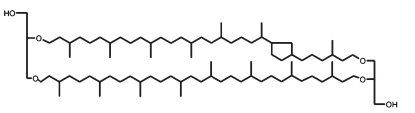

IV.

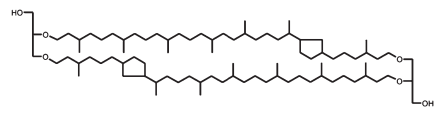

v.

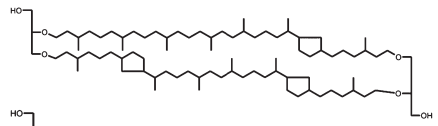

VI.

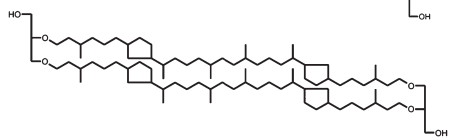

VII.

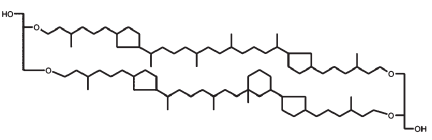

VIII.

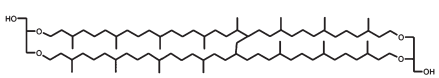

IX.

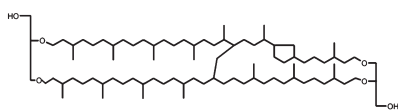

X.

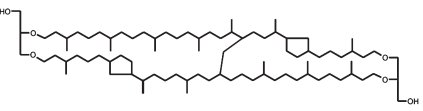

XI.

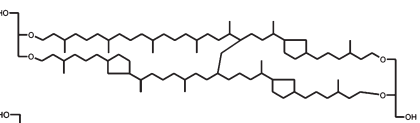

XII.

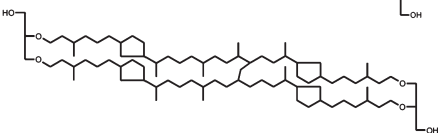

temperatures were generally lower than in black smokers. Thus, there are possibly other parameters controlling the GDGT lipid composition in archaea, for example, $\mathrm{pH}$, pressure, heavy metal content as well as biological factors. For the thermoacidophilic archaea Sulfolobus acidocaldari$u s$, it has been shown that the incorporation of cyclopentane rings leads to a more tightly packed membrane than one without rings, thus regulating membrane behavior, that is, fluidity or proton permeability (Gabriel \& Chong, 2000).

Crenarchaeol (GDGT VII, Fig. 3) was found in the middle and exterior zones of the chimneys, and only traces could be detected in the interior parts of the chim- ney wall at Menorah GS08-ROVIl(1) (Fig. 5A). In the João sample GS10-ROV9(2), crenarchaeol and the regioisomer accounted for $5 \%$ and $<0.1 \%$, respectively, of the total GDGTs (Fig. 4) (concentration was $1 \mathrm{ng} / \mathrm{g}$ chimney material). The mineralogy of this sample suggests that it is derived from the chimney middle to exterior where marcasite precipitated during chimney growth (Haymon, 1983). As for GDGT II-VI, very low concentrations of about $20 \mathrm{pg} / \mathrm{g}$ chimney material were detected in an anhydrite-dominated chimney sample GS09-ROV6(2), clearly showing a seawater sulfate signal (Table 1). Here, crenarchaeol accounted for 25\% of all GDGTs (Fig. 4). Crenarchaeol was originally thought to be a specific 


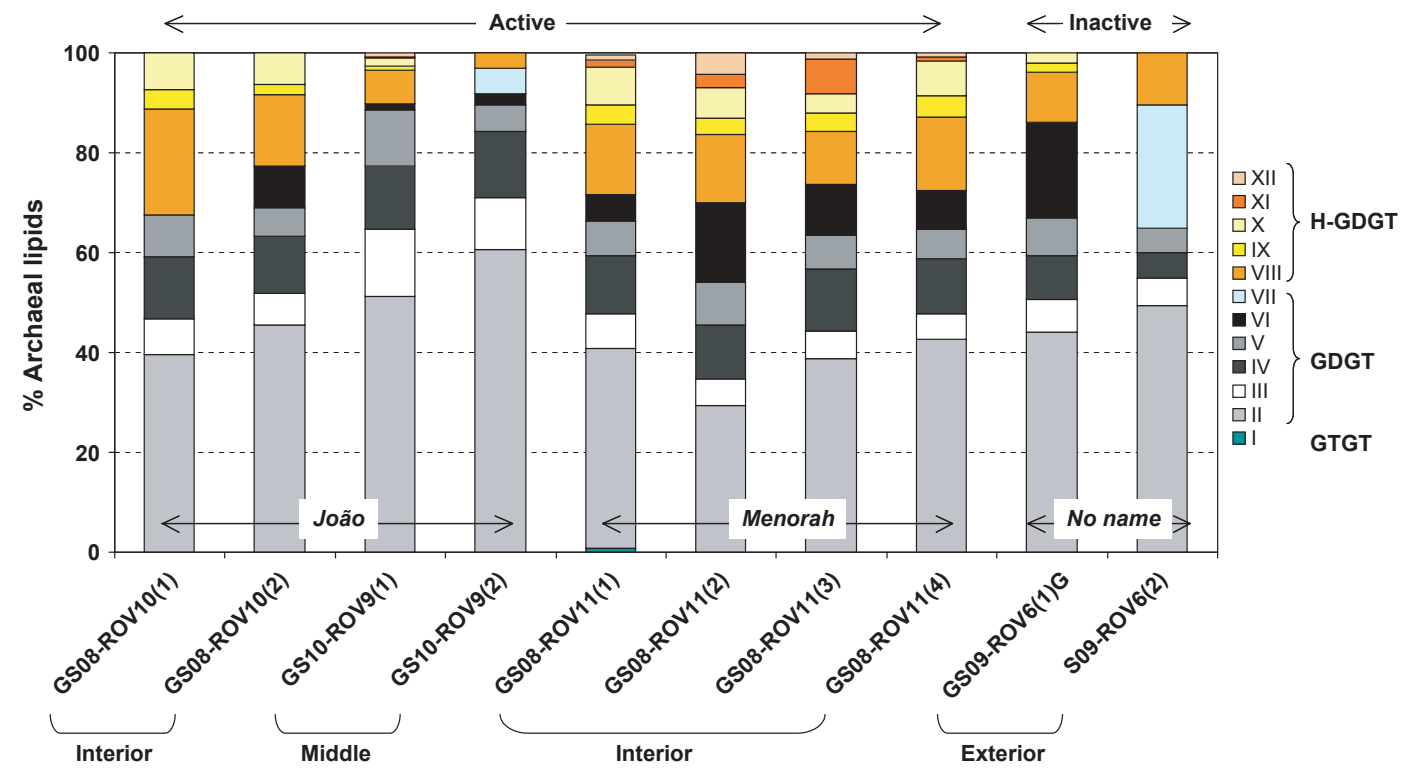

Fig. 4 Relative abundances of archaeal GDGTs present in samples derived from different parts of active and inactive chimneys. Roman numerals refer to structures in Fig. 3. Numbers in brackets indicate subsamples taken from same chimneys.

biomarker for mesophilic Crenarchaeota (recently, the phylum has been split up into two phyla; Crenarchaeota and Thaumarchaeota: Brochier-Armanet et al., 2008; Spang et al., 2010). This group is composed of putative aerobic ammonia oxidizers (AOA) (Könneke et al., 2005; Wuchter et al., 2006) and is ubiquitously found in marine systems between 2 and $30{ }^{\circ} \mathrm{C}$ (Sinninghe Damsté et al., 2002). However, thermophilic members of the ammoniaoxidizing archaea have also been found to synthesize crenarchaeol at temperatures up to $87^{\circ} \mathrm{C}$ (Pearson et al., 2004; Zhang et al., 2006; de la Torre et al., 2008). Loki's Castle is a sediment-impacted hydrothermal system with high ammonium concentrations $\left(6.1 \mathrm{mmol} \mathrm{kg}{ }^{-1}\right.$; $\mathrm{Pe}-$ dersen et al., 2010), suggesting that AOA may be active at this site as well. Moreover, Zhang et al. (2006) suggested that crenarchaeol could be an original and ancient biochemical property of the thermophilic Crenarchaeota, which occupy a deeply branching point in the phylogenetic tree of life (Forterre et al., 2002). Our lipid and 16S rRNA gene-based data, however, suggest that hyperthermophilic Crenarchaeota only account for a small fraction of the total microbial community in the chimney (see discussion previously; Table 2, Fig. 2). Low relative abundances of $16 \mathrm{~S}$ rRNA genes related to marine group I Thaumarchaeota (Table 2, Fig. 2) indicate the presence of AOA. However, chimney walls are sufficiently permeable to allow the influx of small amounts seawater; therefore, our data could also be interpreted as an introduction of Thaumarchaeal cells from the ingression of ambient seawater where they have been found to be ubiquitous (Takai et al., 2004).
Distribution and origin of archaeal H-GDGTS (VIII-XII) In addition to GDGTs I-VII, another group of later-eluting compounds was present in the HPLC/MS chromatogram (VIII-XII, Fig. 3). These compounds showed mass spectra characteristic of GDGTs with base peak ions of 1300, 1298, 1296, 1294, and 1292, respectively, which are the $[\mathrm{M}+\mathrm{H}]^{+}$ions (Fig. 5A). The distribution of these compounds is similar to that of GDGTs II-VII, and they were further identified and distinguished via their $\mathrm{MS}^{2}$ spectra. $\mathrm{MS}^{2}$ experiments revealed that GDGTs VIII-XII have a different fractionation pattern than GDGT II-VII, exhibiting a far less pronounced degree of dissociation (Fig. 5B,C). This is due to the covalent bond between the two hydrocarbon chains in these compounds, which stays intact during the dissociation, generating a product ion that maintains the $\mathrm{C}_{80}$ hydrocarbon core, and two small fragments resulting from the loss of an $\mathrm{OH}$ and a glycerol group. The $\mathrm{MS}^{2}$ spectra are identical to those previously published by Knappy et al. (2009) who analyzed cells from a pure culture of Methanobacter thermoantotrophicus grown at $70^{\circ} \mathrm{C}$. The specific $\mathrm{MS}^{2}$ spectrum indicates that compounds VIII-XII are GDGTs with an additional covalent bond between the isoprenoid chains, so-called $\mathrm{H}$-shaped GDGTs (H-GDGTs) (Morii et al., 1998). Abundances of H-GDGTs VIII-XII are generally lower than those of regular GDGTs (Fig. 3), and contribute with $3-21 \%$ to the total lipid pool (Fig. 4). H-shaped isoprenoid GDGTs have so far been identified in several cultivated archaea, for example, in the above-mentioned hyperthermophilic Methanobacter thermoantotrophicus, in the hyperthermophilic methanogen Methanothermus fervidus (Morii et al., 1998), 

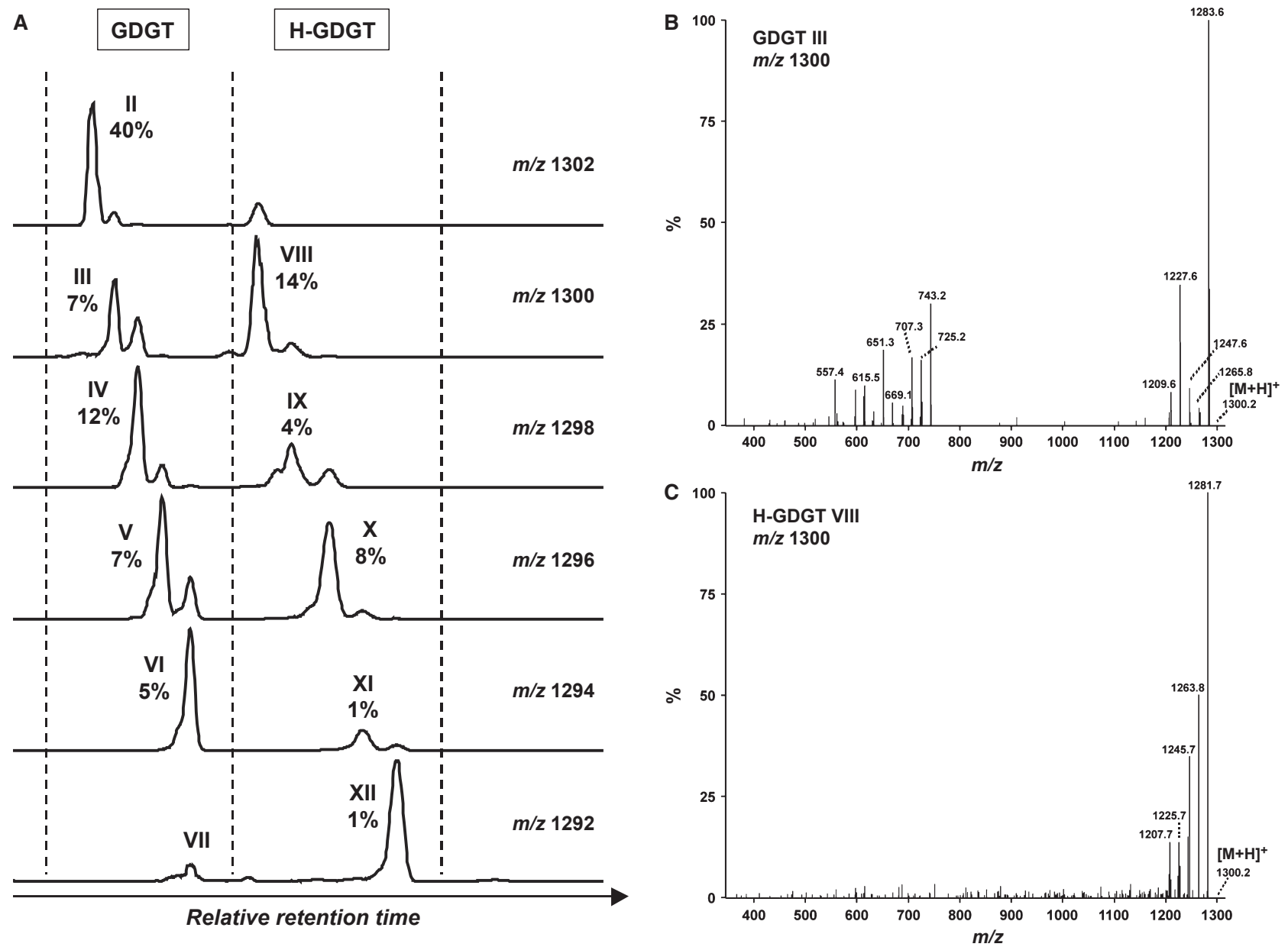

Fig. 5 (A) Individual ion chromatograms for glycerol dialkyl glycerol tetraethers (GDGTs) II-X detected in Menorah active chimney material GS08-ROV11(1) in the positive ion MS base peak chromatogram. The percentage of the total extract contributed by each lipid is also shown. MS ${ }^{2}$ spectra for (B) GDGT II and (C) H-GDGT VIII with $[\mathrm{M}+\mathrm{H}]^{+}$at $\mathrm{m} / \mathrm{z} 1300.2$.

as well as in different species of the order Thermococcales growing at neutral $\mathrm{pH}$ with optimal growth temperatures $>80{ }^{\circ} \mathrm{C}$ (Godfroy et al., 1997; Sugai et al., 2004). In congruence with this, we found a high abundance of Thermococcales-related $16 \mathrm{~S}$ rRNA gene sequences $(28.4 \%$ of total community) (Table 2, Fig. 2), suggesting that this group is the main source of H-GDGTs. Thermococcus is an obligate anaerobic, sulfur-reducing heterotroph belonging to the Euryarchaeota, which is often detected as a member of vent communities (Takai et al., 2001; Schrenk et al., 2003; Kormas et al., 2006; Takai \& Nakamura, 2011). Sulfur reduction has been suggested to be the thermodynamically favored reaction at higher temperatures $\left(>38^{\circ} \mathrm{C}\right)$, while sulfur oxidation is more viable at lower temperatures (McCollom \& Shock, 1997). Elemental sulfur is either stimulatory or is required for growth of Thermococcus. Elevated hydrogen concentrations measured in the vent fluids (Pedersen et al., 2010) can serve as an electron donor for the reduction of elemental sulfur to $\mathrm{H}_{2} \mathrm{~S}$.
Another candidate group for the high abundance of H-GDGTs was identified by Schouten et al. (2008) who detected H-shaped GDGTs with up to four cyclopentane rings in Aciduliprofundum boonei, a cultivated thermoacidophilic sulfur- and iron-reducing Euryarchaeota from a deep-sea hydrothermal vent. This organism belongs to the DHVE2 cluster and is capable of growing from $\mathrm{pH} 3.3$ to 5.8 and between 55 and $75^{\circ} \mathrm{C}$ (Reysenbach et al., 2006). However, at Loki's Castle, 16S rRNA genes related to the DHVE2 cluster contributed only $0.3 \%$ to the total microbial community (Table 2, Fig. 2), indicating that only a minor part of the H-GDGTs originates from those archaea.

Our finding of high abundances H-shaped GDGTs is not surprising as the introduction of an additional covalent cross-link between the isoprenoid chains is thought to help maintain membrane structure at high temperatures (Morii et al., 1998; Schouten et al., 2008). Our results indicating the prevalence of archaeal communities near the warm interior of black smoker chimneys is also in agreement with 
earlier findings by Schrenk et al. (2003). Higher rigidity and stability of archaeal tetraether lipids that form monolayer membranes are better suited to extreme environments than the ester type of bilayer lipids of bacteria or eukarya (van de Vossenberg et al., 1998). Moreover, relatively high abundances of both GDGTs and H-GDGTs with $1-4$ cyclopentane rings detected in our samples is compatible with culture studies showing that (hyper)thermophilic Crenarchaeota and Euryarchaeota produce GDGTs containing more cyclopentane moieties with increasing growth temperature (Uda et al., 2001, 2004). As discussed previously, the distribution of archaeal GDGTs and H-GDGTs could also be controlled by other parameters such as $\mathrm{pH}$, pressure, heavy metal content or it could be related to a specific metabolism (Uda et al., 2004; Boyd et al., 2011). GDGT abundances in samples derived from the exterior wall of the inactive chimney GS09-ROV6 $(1+2)$ were about three orders of magnitude lower than those derived from active chimneys, suggesting that once a chimney stops venting, conditions are no longer favorable for archaeal communities. In our sample of the exterior wall of the inactive chimney, high abundances of unsaturated (and branched) fatty acids were detected and may indicate the presence of sulfur-oxidizing

Table 3 Concentration of distinctive compounds extracted from active and inactive chimney material and chimney-associated filaments

\begin{tabular}{|c|c|c|c|c|}
\hline Compound & $\begin{array}{l}\text { Active } \\
\text { GS08- } \\
\text { ROV11(1) } \\
\text { Menorah } \\
\left(\mathrm{ng} \mathrm{g}^{-1}\right)\end{array}$ & $\begin{array}{l}\text { Filaments } \\
\text { GS09- } \\
\text { ROV9(2) } \\
\text { João } \\
\left(\mu \mathrm{g} \mathrm{g}^{-1}\right)\end{array}$ & $\begin{array}{l}\text { Inactive } \\
\text { GS09- } \\
\text { ROV6(1) } \\
\text { unknown } \\
\left(\mathrm{ng} \mathrm{g}^{-1}\right)\end{array}$ & $\begin{array}{l}\text { Inactive } \\
\text { GS09- } \\
\text { ROV6(2) } \\
\text { unknown } \\
\left(\text { ng g }^{-1} \text { ) }\right.\end{array}$ \\
\hline \multicolumn{5}{|l|}{ Fatty acids } \\
\hline$i-C 15: 0$ & nd & 778 & nd & nd \\
\hline$a i-C 15: 0$ & nd & 549 & nd & nd \\
\hline$a i-C 16: 0$ & nd & 236 & nd & 12.5 \\
\hline$C 16: 1 \omega 7 c$ & nd & 17577 & 192.9 & 1074.2 \\
\hline $\mathrm{C} 16: 1 \omega 7 \mathrm{t}$ & nd & 1985 & 26.3 & 114.2 \\
\hline$C 16: 1 \omega 5 c$ & nd & 2485 & 26.2 & 77.7 \\
\hline $\mathrm{C} 16: 0$ & nd & 5350 & 37.1 & 314.0 \\
\hline 10-Me-C16:0 & nd & nd & nd & 10.8 \\
\hline $\mathrm{C} 18: 1 \omega 9 \mathrm{c}$ & nd & nd & 15.6 & 24.9 \\
\hline $\mathrm{C} 18: 1 \omega 7 \mathrm{c}$ & nd & 6361 & 31.6 & 100.2 \\
\hline C18:0 & nd & 266 & nd & nd \\
\hline$C 22: 1 \omega 9 c$ & nd & nd & 732.2 & 282.1 \\
\hline \multicolumn{5}{|l|}{ Alcohols } \\
\hline Archaeol & 102.2 & $3.1^{*}$ & nd & nd \\
\hline sn-2-hydroxyarchaeol & 68.0 & nd & nd & nd \\
\hline \multicolumn{5}{|l|}{ Hydrocarbons } \\
\hline Crocetane & 3.1 & nd & nd & nd \\
\hline PME & 6.8 & nd & nd & nd \\
\hline PME:4 & 25.9 & nd & nd & nd \\
\hline \multicolumn{5}{|l|}{ Hopanoids } \\
\hline diploptene & 29.2 & nd & nd & nd \\
\hline diplopterol & 15.2 & nd & nd & nd \\
\hline
\end{tabular}

nd, not detected. ${ }^{*}$ sample contained small amounts of rock debris. Also glycerol dialkyl glycerol tetraethers (GDGTs) and H-GDGTs were detected in low abundances $\left(<1 \mu \mathrm{g} \mathrm{g}^{-1}\right)$. (and sulfate-reducing) members of the $\varepsilon$ subclass of the Proteobacteria (the $\varepsilon$-Proteobacteria) (Table 3 ; see section on bacteria below; H. Dahle, unpublished data).

\section{Isoprenoid diether lipids and hydrocarbons}

Isoprenoid compounds of archaeal origin, such as archaeol, were also found in the Menorah sample GS08-ROV11(1). Archaeol is produced by a variety of different archaeal groups, such as halophiles, thermophiles, and acidophiles (Koga \& Morii, 2005), and was present with a concentration of $102 \mathrm{ng} / \mathrm{g}$ (Table 3). Another isoprenoid compound, sn-2-hydroxyarchaeol, was detected as both mono- and di-trimethylsilyl (TMS) derivatives with a concentration of $68 \mathrm{ng} / \mathrm{g}$. $s n$-2-hydroxyarchaeol is a diagnostic biomarker for the thermoacidophilic archaeal order Thermoplasmatales and the methanogenic order Methanococcales (Koga et al., 1998), which is consistent with the findings of abundant GDGTs with cyclopentyl moieties as well as $16 \mathrm{~S}$ rRNA gene-based taxonomy data (see section above; Table 2). Concentrations of crocetane, irregular isoprenoids pentamethyleicosane (PME) and PME 4 were 3,7 , and $26 \mathrm{ng} / \mathrm{g}$ chimney material, respectively. These compounds have been attributed to anaerobic, methanotrophic archaea (ANME) (Elvert et al., 1999; Bian et al., 2001), although PME was originally believed to be synthesized by methanogenic archaea (Holzer et al., 1979; Risatti et al., 1984). Whereas the presence of methanogenic archaea is supported by our I6S rRNA gene data (methanococci), no sequences related to any of the ANME groups were detected.

\section{Bacteria}

The lipid composition of large filamentous bacteria collected from the João active sulfide chimney (GS09-ROV9) revealed the dominance of $\mathrm{C}_{16: 1 \omega 7 \mathrm{c}}(47 \%), \mathrm{C}_{18: 1 \omega 7 \mathrm{c}}(17 \%)$, and $\mathrm{C}_{16: 0}$ (14\%) fatty acids. Concentrations of these compounds are about three orders of magnitude higher in this sample as in the chimney material (Table 3 ). The lipid pattern is consistent with lipid profiles of known sulfur-oxidizing bacteria from sediments and hydrothermal vents (Jacq et al., 1989; Guezennec et al., 1998; Zhang et al., 2005). The filaments attached to the outer chimney wall have been found to be related to sulfur-oxidizing bacteria Sulfurovum, a group belonging to the $\varepsilon$-Proteobacteria that thrive at lower ambient temperatures ( $\mathrm{H}$. Dahle, unpublished data). Minor abundances of $\mathrm{C}_{16: 1 \omega 5 \mathrm{c}}$ and $\mathrm{C}_{18: 1 \omega 9 \mathrm{c}}$ detected in the filaments as well as in the inactive chimney samples GS09-ROV6 $(1+2)$ may be derived from sulfate-reducing bacteria (Dowling et al., 1986; Elvert et al., 2003; Londry et al., 2004).

I6S rRNA gene analysis with subsequent taxonomic analysis of Menorah active chimney GS08-ROV11 revealed that members of the Aquificales and E-Proteobacteria were the dominant bacteria accounting for 26 and $36 \%$ of the total 
prokaryotic community (Table 2). The Aquificales is thought to be the earliest branching lineage within Bacteria and have often been detected in hot springs (Spear et al., 2005; Purcell et al., 2007) and deep-sea vent ecosystems (Kormas et al., 2006; Blumenberg et al., 2012). Among the bacteria, Aquificales exhibit one of the highest growth temperatures $\left(95^{\circ} \mathrm{C}\right)$. They are anaerobic lithoautotrophs, gaining metabolic energy from the oxidation of molecular hydrogen $\left(\mathrm{H}_{2}\right)$ or sulfur compounds. Lithotrophic sulfur reduction by oxidation of $\mathrm{H}_{2}$ is believed to be one of the most ancient types of catabolism (Fischer et al., 1983), and the preferred source of energy at temperatures $>38^{\circ} \mathrm{C}$ (McCollom \& Shock, 1997). The apparent lack of dialkyl glycerol diethers (DAGE) specific for the Aquificales (Jahnke et al., 2001) at Menorah may be because the distinct zones where the Aquificales thrive within the chimney structure were not present in our subsamples for lipid analysis. Another possibility of the observed discrepancy could be a primer bias in the $16 \mathrm{~S}$ rRNA gene approach, leading to a skewed relative abundance estimate. The same may be the case for the deep-branching $\varepsilon$-Proteobacterial group Nautiliales that were detected as one of the main organisms within the chimney wall of Menorah (Table 2). Nautiliales is believed to be constituted of thermophilic sulfur-reducing bacteria that are found to be key players in sulfidic habitats (Alain et al., 2004; Campbell et al., 2006). Other members of the $\varepsilon$-Proteobacteria, for example, the Campylobacteriales, made up only a very small fraction of the total population (data not shown). The dominant lipids of Nautilia profundicola have been shown to be $\mathrm{C}_{18: 1 \omega 7 \mathrm{c}}$ and $\mathrm{C}_{16: 1 \omega 7 \mathrm{c}}$ fatty acids (Smith et al., 2008). High abundances of branched and monounsaturated fatty acids detected in samples derived from the outer chimney wall GS09-ROV6 $(1+2)$ (Table 3 ) may be produced by sulfur-oxidizing and sulfate-reducing bacteria. In general, lower growth temperatures of $45-53{ }^{\circ} \mathrm{C}$ indicate that bacteria mainly thrive within the exterior chimney walls, which has also been reported for a white smoker by Kormas et al. (2006). The hopanoids diploptene and diplopterol with low concentrations (Table 3 ) have predominantly been found in aerobic bacteria, that is, methanotrophs, heterotrophs, and cyanobacteria. Hopanoids also occur in anaerobic bacteria, for example, members of the Planctomycetes capable of anaerobic ammonium oxidation (Sinninghe Damsté et al., 2004), in Geobacter species (Fischer et al., 2005; Härtner et al., 2005), and in sulfate-reducing bacteria of the genus Desulfovibrio (Blumenberg et al., 2006). Concentrations of these lipids, however, are about 1-2 orders of magnitude lower than measured for GDGTs.

\section{CONCLUSIONS}

In the present study, we gave first insights into the diversity of microbial communities present in sulfide structures of active and inactive vents from the newly discovered Loki's Castle black smoker field at the Arctic Mid-Ocean Ridge. Evidence for both archaea and bacteria was provided by a combination of lipid biomarker and $16 \mathrm{~S}$ rRNA gene-based techniques. The specific lipid distribution observed in samples derived from different parts of the active and inactive chimneys indicate the presence of diverse consortia of (hyper)thermophilic Euryarchaeota and Crenarchaeota within the warmer interior zones, while bacterial lipids were only a minor constituent. Our study particularly showed that H-GDGTs, which have to date not been reported from archaea under environmental conditions, were abundant in all samples. With additional $16 \mathrm{~S}$ rRNA gene data available, these compounds could also be linked with their potential source organisms which may be (hyper)thermophilic members of the Thermococcaceae. Based on biomarker lipid and 16S rRNA gene analyses, we conclude that sulfur reduction by (hyper)thermophilic archaea and bacteria as well as archaeal methanogenesis are the most likely metabolic activities within the interior zones of the black smoker chimney walls at Loki's Castle. Bacterial sulfur oxidation and sulfate reduction as well as ammonia oxidation are favorable metabolisms in the exterior zones of the chimney walls.

\section{ACKNOWLEDGMENTS}

We would like to thank the crew of R/V G.O. Sars for shipboard support and Tamara Baumberger for help with sampling. We also greatly appreciate the help with the bioinformatics from Anders Lanzén. Our special acknowledgements go to Carme Huguet and one anonymous reviewer for comments and suggestions considerably improving the quality of the manuscript. The Norwegian High-throughput sequencing Centre at the University of Oslo performed the sequencing. (http://www.sequencing. uio.no). This work was supported by the Swiss National Science Foundation (SNF projects 20MA21-115916 and 200020-132804).

\section{REFERENCES}

Alain K, Zbinden M, Le Bris N, Lesongeur F, Querellou J, Gaill F, Cambon-Bonavita MA (2004) Early steps in microbial colonization processes at deep-sea hydrothermal vents. Environmental Microbiology, 6, 227-241.

Baross JA, Hoffman SE (1985) Submarine hydrothermal vents and associated gradient environments as sites for the origin and evolution of life. Origins of Life and Evolution of the Biosphere, 15, 327-345.

Baumberger T (2011) Volatiles in marine hydrothermal systems. $\mathrm{PhD}$ thesis, ETH Zurich, Switzerland, http://dx.doi.org/ 10.3929/ethz-a-007230100 (accessed 2012).

Bian LQ, Hinrichs KU, Xie TM, Brassell SC, Iversen H, Fossing H, Jorgensen BB, Hayes JM (2001) Algal and archaeal polyisoprenoids in a recent marine sediment: molecular isotopic 
evidence for anaerobic oxidation of methane. Geochemistry Geophysics Geosystems, 2, 2000GC000112.

Bligh EG, Dyer WJ (1959) A rapid method of total lipid extraction and purification. Canadian Journal of Biochemistry and Physiology, 37, 911-917.

Blumenberg M, Krüger M, Nauhaus K, Talbot HM, Oppermann B, Seifert R, Pape T, Michaelis W (2006) Biosynthesis of hopanoids by sulfate-reducing bacteria (genus Desulfovibrio). Environmental Microbiology, 8, 1220-1227.

Blumenberg M, Seifert R, Petersen S, Michaelis W (2007) Biosignatures present in a hydrothermal massive sulfide from the Mid-Atlantic Ridge. Geobiology, 5, 435-450.

Blumenberg M, Seifert R, Buschmann B, Kiel S, Thiel V (2012) Biomarkers reveal diverse microbial communities in black smoker sulfides from Turtle Pits (Mid-Atlantic Ridge, Recent) and Yaman Kasy (Russia, Silurian). Geomicrobiology Journal, 29, 66-75.

Boyd ES, Pearson A, Pi YD, Li WJ, Zhang YG, He L, Zhang CL, Geesey GG (2011) Temperature and pH controls on glycerol dibiphytanyl glycerol tetraether lipid composition in the hyperthermophilic crenarchaeon Acidilobus sulfurireducens. Extremophiles, 15, 59-65.

Bradley AS, Hayes JM, Summons RE (2009) Extraordinary (13)C enrichment of diether lipids at the lost city hydrothermal field indicates a carbon-limited ecosystem. Geochimica Et Cosmochimica Acta, 73, 102-118.

Brochier-Armanet C, Boussau B, Gribaldo S, Forterre P (2008) Mesophilic Crenarchaeota: proposal for a third archaeal phylum, the Thaumarchaeota. Nature Reviews Microbiology, 6, 245-252.

Campbell BJ, Engel AS, Porter ML, Takai K (2006) The versatile epsilon-proteobacteria: key players in sulphidic habitats. Nature Reviews Microbiology, 4, 458-468.

Corliss JB, Dymond J, Gordon LI, Edmond JM, Herzen RPV, Ballard RD, Green K, Williams D, Bainbridge A, Crane K, Vanandel TH (1979) Submarine thermal springs on the Galapagos rift. Science, 203, 1073-1083.

Derosa M, Gambacorta A (1988) The lipids of Archaebacteria. Progress in Lipid Research, 27, 153-175.

Dowling NJE, Widdel F, White DC (1986) Phospholipid esterlinked fatty acid biomarkers of acetate-oxidizing sulfate-reducers and other sulfide-forming bacteria. Journal of General Microbiology, 132, 1815-1825.

Elvert M, Suess E, Whiticar MJ (1999) Anaerobic methane oxidation associated with marine gas hydrates: superlight C-isotopes from saturated and unsaturated C-20 and C-25 irregular isoprenoids. Naturwissenschaften, 86, 295-300.

Elvert M, Boetius A, Knittel K, Jorgensen BB (2003) Characterization of specific membrane fatty acids as chemotaxonomic markers for sulfate-reducing bacteria involved in anaerobic oxidation of methane. Geomicrobiology Journal, 20, 403-419.

Fischer F, Zillig W, Stetter KO, Schreiber G (1983) Chemolithoautotrophic metabolism of anaerobic extremely thermophilic archaebacteria. Nature, 301, 511-513.

Fischer WW, Summons RE, Pearson A (2005) Targeted genomic detection of biosynthetic pathways: anaerobic production of hopanoid biomarkers by a common sedimentary microbe. Geobiology, 3, 33-40.

Forterre P, Brochier C, Philippe H (2002) Evolution of the archaea. Theoretical Population Biology, 61, 409-422.

Gabriel JL, Chong PLG (2000) Molecular modeling of archaebacterial bipolar tetraether lipid membranes. Chemistry and Physics of Lipids, 105, 193-200.

Godfroy A, Lesongeur F, Raguenes G, Querellou J, Antoine E, Meunier JR, Guezennec J, Barbier G (1997) Thermococcus hydrothermalis sp. nov, a new hyperthermophilic Archaeon isolated from a deep-sea hydrothermal vent. International Journal of Systematic Bacteriology, 47, 622-626.

Guezennec J, Ortega-Morales O, Raguenes G, Geesey G (1998) Bacterial colonization of artificial substrate in the vicinity of deepsea hydrothermal vents. Fems Microbiology Ecology, 26, 89-99.

Gulik A, Luzzati V, Derosa M, Gambacorta A (1988) Tetraether lipid components from a thermoacidophilic archaebacterium chemical-structure and physical polymorphism. Journal of Molecular Biology, 201, 429-435.

Hafenbradl D, Keller M, Dirmeier R, Rachel R, Rossnagel P, Burggraf S, Huber H, Stetter KO (1996) Ferroglobus placidus gen nov, sp nov, a novel hyperthermophilic archaeum that oxidizes $\mathrm{Fe} 2+$ at neutral $\mathrm{pH}$ under anoxic conditions. Archives of Microbiology, 166, 308-314.

Härtner T, Straub KL, Kannenberg E (2005) Occurrence of hopanoid lipids in anaerobic Geobacter species. FEMS Microbiology Letters, 243, 59-64.

Haymon RM (1983) Growth history of hydrothermal black smoker chimneys. Nature, 301, 695-698.

Haymon RM, Kastner M (1981) Hot spring deposits on the East Pacific Rise at $21^{\circ} \mathrm{N}$ : preliminary description of mineralogy and genesis. Earth and Planetary Science Letters, 53, 363-381.

Holzer G, Oro J, Tornabene TG (1979) Gas chromatographicmass spectrometric analysis of neutral lipids from methanogenic and thermoacidophilic bacteria. Journal of Chromatography, 186, 795-809.

Hopmans EC, Schouten S, Pancost RD, van der Meer MTJ, Sinninghe Damsté JS (2000) Analysis of intact tetraether lipids in archaeal cell material and sediments by high performance liquid chromatography/atmospheric pressure chemical ionization mass spectrometry. Rapid Communications in Mass Spectrometry, 14, 585-589.

Huber H, Stetter KO (2006) Desulfurococcales. In The Prokaryotes (eds Dworkin M, Falkow S, Rosenberg E, Schleifer K-H, Stackebrandt E). Springer, New York, pp. 52-68.

Hugenholtz P, Goebel BM, Pace NR (1998) Impact of cultureindependent studies on the emerging phylogenetic view of bacterial diversity (vol 180, pg 4765, 1998). Journal of Bacteriology, 180, 6793.

Huson DH, Auch AF, Qi J, Schuster SC (2007) MEGAN analysis of metagenomic data. Genome Research, 17, 377-386.

Jacq E, Prieur D, Nichols P, White DC, Porter T, Geesey GG (1989) Microscopic examination and fatty acid characterization of filamentous bacteria colonizing substrate around subtidal hydrothermal vents. Archives of Microbiology, 152, 64-71.

Jahnke LL, Eder W, Huber R, Hope JM, Hinrichs KU, Hayes JM, Des Marais DJ, Cady SL, Summons RE (2001) Signature lipids and stable carbon isotope analyses of octopus spring hyperthermophilic communities compared with those of Aquificales representatives. Applied and Environmental Microbiology, 67, 5179-5189.

Karl DM (1995) Ecology of Free-living, Hydrothermal Vent Communities. CRC, New York.

Kato S, Takano Y, Kakegawa T, Oba H, Inoue K, Kobayashi C, Utsumi M, Marumo K, Kobayashi K, Ito Y, Ishibashi JI, Yamagishi A (2010) Biogeography and biodiversity in sulfide structures of active and inactive vents at deep-sea hydrothermal fields of the Southern Mariana trough. Applied and Environmental Microbiology, 76, 2968-2979.

Knappy CS, Chong JPJ, Keely BJ (2009) Rapid discrimination of archaeal tetraether lipid cores by liquid chromatography-tandem mass spectrometry. Journal of the American Society for Mass Spectrometry, 20, 51-59. 
Koga Y, Morii H (2005) Recent advances in structural research on ether lipids from archaea including comparative and physiological aspects. Bioscience Biotechnology and Biochemistry, 69, 2019-2034.

Koga Y, Morii H (2007) Biosynthesis of ether-type polar lipids in archaea and evolutionary considerations. Microbiology and Molecular Biology Reviews, 71, 97-120.

Koga Y, Morii H, Akagawa-Matsushita M, Ohga I (1998) Correlation of polar lipid composition with 16S rRNA phylogeny in methanogens. Further analysis of lipid component parts. Bioscience Biotechnology and Biochemistry, 62, 230-236.

Könneke M, Bernhard AE, de la Torre JR, Walker CB, Waterbury JB, Stahl DA (2005) Isolation of an autotrophic ammoniaoxidizing marine archaeon. Nature, 437, 543-546.

Kormas KA, Tivey MK, Von Damm K, Teske A (2006) Bacterial and archaeal phylotypes associated with distinct mineralogical layers of a white smoker spire from a deep-sea hydrothermal vent site $\left(9^{\circ} \mathrm{N}\right.$, East Pacific Rise). Environmental Microbiology, 8, 909-920.

Lane DJ, Pace B, Olsen GJ, Stahl DA, Sogin ML, Pace NR (1985) Rapid-Determination of 16 S ribosomal-RNA sequences for phylogenetic analyses. Proceedings of the National Academy of Sciences of the United States of America, 82, 6955-6959.

Lanzén A, Jørgensen SL, Bengtsson MM, Jonassen I, Øvreas L, Urich T (2011) Exploring the composition and diversity of microbial communities at the Jan Mayen hydrothermal vent field using RNA and DNA. Fems Microbiology Ecology, 77, 577589

Londry KL, Jahnke LL, Des Marais DJ (2004) Stable carbon isotope ratios of lipid biomarkers of sulfate-reducing bacteria. Applied and Environmental Microbiology, 70, 745-751.

Macalady JL, Vestling MM, Baumler D, Boekelheide N, Kaspar CW, Banfield JF (2004) Tetraether-linked membrane monolayers in Ferroplasma spp: a key to survival in acid. Extremophiles, 8, 411-419.

Martin W, Baross J, Kelley D, Russell MJ (2008) Hydrothermal vents and the origin of life. Nature Reviews Microbiology, 6, 805 -814 .

McCollom TM, Shock EL (1997) Geochemical constraints on chemolithoautotrophic metabolism by microorganisms in seafloor hydrothermal systems. Geochimica Et Cosmochimica Acta, 61, 4375-4391.

Miroshnichenko ML (2004) Thermophilic microbial communities of deep-sea hydrothermal vents. Microbiology, 73, 1-13.

Morii H, Eguchi T, Nishihara M, Kakinuma K, Konig H, Koga Y (1998) A novel ether core lipid with H-shaped C-80-isoprenoid hydrocarbon chain from the hyperthermophilic methanogen Methanothermus fervidus. Biochimica Et Biophysica Acta-Lipids and Lipid Metabolism, 1390, 339-345.

Murowchick JB, Barnes HL (1986) Marcasite precipitation from hydrothermal solutions. Geochimica Et Cosmochimica Acta, 50, 2615-2629.

Nichols PD, Guckert JB, White DC (1986) Determination of monounsaturated fatty-acid double-bond position and geometry for microbial monocultures and complex consortia by capillary Gc-Ms of their dimethyl disulfide adducts. Journal of Microbiological Methods, 5, 49-55.

Pearson A, Huang Z, Ingalls AE, Romanek CS, Wiegel J, Freeman $\mathrm{KH}$, Smittenberg RH, Zhang CL (2004) Nonmarine crenarchaeol in Nevada hot springs. Applied and Environmental Microbiology, 70, 5229-5237.

Pedersen RB, Rapp HT, Thorseth IH, Lilley MD, Barriga FJAS, Baumberger T, Flesland K, Fonseca R, Fruh-Green GL, Jorgensen SL (2010) Discovery of a black smoker vent field and vent fauna at the Arctic Mid-Ocean Ridge. Nature Communications, 1, 126. doi: 10.1038/ncomms1 124.

Pruesse E, Quast C, Knittel K, Fuchs BM, Ludwig WG, Peplies J, Glockner FO (2007) SILVA: a comprehensive online resource for quality checked and aligned ribosomal RNA sequence data compatible with ARB. Nucleic Acids Research, 35, 7188-7196.

Purcell D, Pointing SB, Sompong U, Yim LC, Barraclough TG, Peerapornpisal Y (2007) The effects of temperature, $\mathrm{pH}$ and sulphide on the community structure of hyperthermophilic streamers in hot springs of northern Thailand. Fems Microbiology Ecology, 60, 456-466.

Quince C, Lanzen A, Davenport RJ, Turnbaugh PJ (2011) Removing noise from pyrosequenced amplicons. $B M C$ Bioinformatics, 12, 38 .

Reysenbach AL, Liu YT, Banta AB, Beveridge TJ, Kirshtein JD, Schouten S, Tivey MK, Von Damm KL, Voytek MA (2006) A ubiquitous thermoacidophilic archaeon from deep-sea hydrothermal vents. Nature, 442, 444-447.

Risatti JB, Rowland SJ, Yon DA, Maxwell JR (1984) Stereochemical studies of acyclic isoprenoids-XI. Lipids of methanogenic bacteria and possible contributions to sediments. Organic Geochemistry, 6, 93-114.

Roesch LF, Fulthorpe RR, Riva A, Casella G, Hadwin AKM, Kent AD, Daroub SH, Camargo FAO, Farmerie WG, Triplett EW (2007) Pyrosequencing enumerates and contrasts soil microbial diversity. Isme Journal, 1, 283-290.

Schouten S, Hopmans EC, Schefuss E, Sinninghe Damsté JS (2002) Distributional variations in marine crenarchaeotal membrane lipids: a new tool for reconstructing ancient sea water temperatures? Earth and Planetary Science Letters, 204, 265-274

Schouten S, van der Meer MTJ, Hopmans EC, Rijpstra WIC, Reysenbach AL, Ward DM, Sinninghe Damsté JS (2007) Archaeal and bacterial glycerol dialkyl glycerol tetraether lipids in hot springs of Yellowstone National Park. Applied and Environmental Microbiology, 73, 6181-6191.

Schouten S, Baas M, Hopmans EC, Reysenbach AL, Sinninghe Damsté JS (2008) Tetraether membrane lipids of Candidatus "Aciduliprofundum boonei", a cultivated obligate thermoacidophilic euryarchaeote from deep-sea hydrothermal vents. Extremophiles, 12, 119-124.

Schrenk MO, Kelley DS, Delaney JR, Baross JA (2003) Incidence and diversity of microorganisms within the walls of an active deep-sea sulfide chimney. Applied and Environmental Microbiology, 69, 3580-3592.

Shanks WC, Seyfried WE (1987) Stable isotope studies of vent fluids and chimney minerals, southern Juan-De-Fuca Ridge Sodium metasomatism and seawater sulfate reduction. Journal of Geophysical Research-Solid Earth and Planets, 92, 1138711399.

Sinninghe Damsté JS, Schouten S, Hopmans EC, van Duin ACT, Geenevasen JAJ (2002) Crenarchaeol: the characteristic core glycerol dibiphytanyl glycerol tetraether membrane lipid of cosmopolitan pelagic crenarchaeota. Journal of Lipid Research, 43, 1641-1651.

Sinninghe Damsté JS, Rijpstra WIC, Schouten S, Fuerst JA, Jetten MSM, Strous M (2004) The occurrence of hopanoids in planctomycetes: implications for the sedimentary biomarker record. Organic Geochemistry, 35, 561-566.

Smith JL, Cary SC, Campbell BJ, Hanson TE, Zhang CL (2008) Nautilia profundicola sp nov., a thermophilic, sulfur-reducing epsilonproteobacterium from deep-sea hydrothermal vents. International Journal of Systematic and Evolutionary Microbiology, 58, 1598-1602. 
Sogin ML, Morrison HG, Huber JA, Mark Welch D, Huse SM, Neal PR, Arrieta JM, Herndl GJ (2006) Microbial diversity in the deep sea and the underexplored "rare biosphere". Proceedings of the National Academy of Sciences of the United States of America, 103, 12115-12120.

Spang A, Hatzenpichler R, Brochier-Armanet C, Rattei T, Tischler P, Spieck E, Streit W, Stahl DA, Wagner M, Schleper C (2010) Distinct gene set in two different lineages of ammonia-oxidizing archaea supports the phylum Thaumarchaeota. Trends in Microbiology, 18, 331-340.

Spear JR, Walker JJ, McCollom TM, Pace NR (2005) Hydrogen and bioenergetics in the Yellowstone geothermal ecosystem. Proceedings of the National Academy of Sciences of the United States of America, 102, 2555-2560.

Stetter K (2002) The Genus Archaeoglobus. Springer, Berlin Heidelberg New York.

Stetter KO (2006) History of discovery of the first hyperthermophiles. Extremophiles, 10, 357-362.

Stetter KO, Lauerer G, Thomm M, Neuner A (1987) Isolation of extremely thermophilic sulfate reducers - evidence for a novel branch of archaebacteria. Science, 236, 822-824.

Sugai A, Uda I, Itoh YH, Itoh T (2004) The core lipid composition of the 17 strains of hyperthermophilic archaea, Thermococcales. Journal of Oleo Science, 53, 41-44.

Takai K, Nakamura K (2011) Archaeal diversity and community development in deep-sea hydrothermal vents. Current Opinion in Microbiology, 14, 282-291.

Takai K, Komatsu T, Inagaki F, Horikoshi K (2001) Distribution of archaea in a black smoker chimney structure. Applied and Environmental Microbiology, 67, 3618-3629.

Takai K, Oida H, Suzuki Y, Hirayama H, Nakagawa S, Nunoura T, Inagaki F, Nealson KH, Horikoshi K (2004) Spatial distribution of marine crenarchaeota group $\mathrm{I}$ in the vicinity of deep-sea hydrothermal systems. Applied and Environmental Microbiology, 70, 2404-2413.

Tivey MK (1995) The influence of hydrothermal fluid composition and advection rates on black smoker chimney mineralogy - insights from modeling transport and reaction. Geochimica Et Cosmochimica Acta, 59, 1933-1949.

de la Torre JR, Walker CB, Ingalls AE, Konneke M, Stahl DA (2008) Cultivation of a thermophilic ammonia oxidizing archaeon synthesizing crenarchaeol. Environmental Microbiology, 10, 810-818.

Uda I, Sugai A, Itoh YH, Itoh T (2001) Variation in molecular species of polar lipids from Thermoplasma acidophilum depends on growth temperature. Lipids, 36, 103-105.

Uda I, Sugai A, Itoh YH, Itoh T (2004) Variation in molecular species of core lipids from the order Thermoplasmatalesstrains depend on growth temperature. Journal of Oleo Science, 53, 399-404.

van de Vossenberg JLCM, Driessen AJM, Konings WN (1998) The essence of being extremophilic: the role of the unique archaeal membrane lipids. Extremophiles, 2, 163-170.

Wuchter C, Abbas B, Coolen MJL, Herfort L, van Bleijswijk J, Timmers P, Strous M, Teira E, Herndl GJ, Middelburg JJ, Schouten S, Sinninghe Damsté JS (2006) Archaeal nitrification in the ocean. Proceedings of the National Academy of Sciences of the United States of America, 104, 5704.

Zhang CL, Huang ZY, Cantu J, Pancost RD, Brigmon RL, Lyons TW, Sassen R (2005) Lipid biomarkers and carbon isotope signatures of a microbial (Beggiatoa) mat associated with gas hydrates in the Gulf of Mexico. Applied and Environmental Microbiology, 71, 2106-2112.

Zhang CL, Pearson A, Li YL, Mills G, Wiegel J (2006) Thermophilic temperature optimum for crenarchaeol synthesis and its implication for archaeal evolution. Applied and Environmental Microbiology, 72, 4419-4422. 